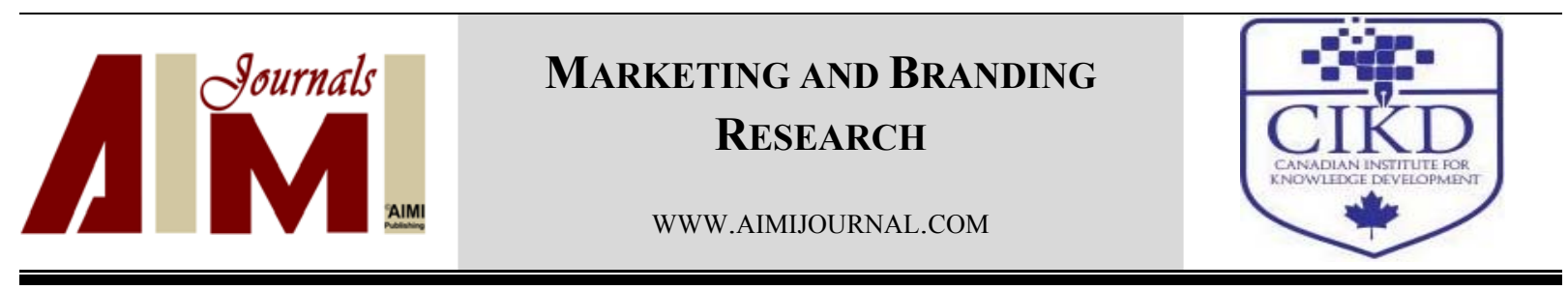

\title{
Importance of Financial Aspects of a Company Crisis Management in Slovakia
}

\author{
Katarína Fedorková
}

University of Economics Bratislava

\begin{abstract}
Keywords:

Company Decline, Crisis

Management, Financial

Management, Financial

Analysis

Correspondence:

katarina.fedorkova7@gmail.com

Received

04 August 2017

Received in revised form

25 January 2018

Accepted

11 February 2018

The first part of the article deals with a company decline as a consequence of the insufficient company performance in connection with its financial instability. We focus on a new legal definition of a company decline and an imminent company decline in Slovakia as well. In enterprises, a decline is resolved by the implementation of a company crisis management by using informal and formal procedures of a company crisis management. Next, we devote to financial aspects of company crisis management in connection with financial management. In the second part, we explain the methodology of work and the used methods of the research within a chosen sample of enterprises. The application part of the article includes the statistics of the testing of declines in a chosen sample of enterprises, where we use the financial analysis as a method of indicating a decline in the sample of enterprises. We test especially the golden balance rule of financing with liquidity and debt ratios as the main financial indicators of a company decline. In the work results and within the discussion we come to the characteristics of a company decline causes and the conclusion is aimed at the recommendations for the economic practice in the field of financial company health with the primary objective to avoid or to avert a company decline with the smallest possible losses.
\end{abstract}

CAIMI Journals

\section{Introduction}

The issue of crisis management is currently a significant part of a financial company management within introducing of crisis methods and measures with the objective to avoid or avert a company decline. One of the basic conditions for adapting to the environment and to necessary changes is a financial stability of a company, what is achieved by a proper financial 
management in a company. Every creditor is interested in a company stability who has an interest in as small indebtedness as possible, what is connected with risk return on his investment to a company. The content of our research are business results that influence a company in a negative way and may cause a decline formation or imminent decline formation. These results include financial situation through which a company appears to its surroundings. Based on the theoretical knowledge and on the review of the research issue, the main objective of the research is to quantify, analyze, and evaluate causes of companies' decline formation.

\section{Financial Management in Connection with Crisis Management}

To be insolvent means not being able to repay at least 2 monetary liabilities 30 days overdue to more than one creditor. An extended is the one who is obligated to keep accounts under special rules, has more than one creditor, and the value of its liabilities exceeds the value of its assets. Taking effect from the beginning of 2016, the law defines the imminent bankruptcy that threatens a debtor particularly if they are in crisis. Hence, the Commercial Code introduced the concept of a company in crisis. A company is in crisis, if there is a low ratio of equity and liabilities, i.e. a low value of the self-financing ratio. In 2016, this ratio is 4 to 100 , where own resources consist of only 4 percent of all company resources. For 2017, this ratio toughens to 6 to 100 and for 2018 to 8 to 100 .

In a company, a decline or imminent decline is solved by introducing of crisis management. Coombs (2007) claims that crisis management is a basic function for organization, because management failure can result in serious consequences for owners and stockholders, losses for organization or even threatens a company existence. We perceive a crisis management as a set of activities, which main functions are planning, organizing, leading, and controlling processes in a company that are focused on solving of the crisis state with using of appropriate methods, policies, and procedures, where the primary target is to overcome the crisis state and eliminate possible negative consequences. We also do not forget the fact that the contents of a crisis management are fields of preventive programs, where the emphasis is put on uncovering potential threats in the enterprise and strengthening the necessary preventive measures. Organizations and individuals should be always prepared to quick reaction that includes various analyses and then the necessary solutions (Bernstein \& Rakowitz, 2012). A decline solving by introducing crisis management includes formal and informal procedures, while formal procedures are law governed procedures - bankruptcy and restructuring. Informal procedures, that are more preferred, do not go under the court supervision and are introduced by, for example, consolidation, informal restructuring, and remediation. If a company is not able to solve the decline by introducing informal procedures, it should do as much as possible to apply procedures of restructuring from the formal procedures, because it secures continuing of a business activity, and there is gradually debt relief and rescue of a company.

We consider the financial aspects to be the most important aspects of crisis management either to solve decline processes or to prevent processing. Since a company appears to its environment most through its financial situation, its financial characteristics and results are the most relevant aspects and financial management belongs to the most important parts of a 
company management. Its role is to manage the financial processes. It includes four basic activities, namely financial planning, decision making, organizing of financial processes, and financial analysis with control. Its basic pillar is decision making that focuses on an appropriate choice of optimal capital structure, gaining of monetary resources and its using in connection with achievement of partial financial targets. Many times just an ability to decide properly in fields of financial management decides about a potential formation of financial problems. The assumption of the financial health is securing of financial stability, which is one of the financial partial targets in a company and is achieved by required liquidity, indebtedness, and profitability. A financial strategy is a coherent and connected set of strategic financial goals, decision criteria, and rules that creates the basis of a long-term financial planning of the company (Král'ovič \& Vlachynský, 2011). From a long-term perspective, only companies that can achieve their targets defined in the strategy can be considered as performing. It is necessary to understand the notion of performance as a company ability to best evaluate investments put into business activities (Frost, 2005). One of the basic business goals of a company is maximization of a company market value. Within this, it is appropriate to mention that the company value is determined by its performance and it belongs to a preferred measure of performance, because it requires complete information as the only one (Neumaierová et al., 2005). If we want to increase a company market value, it is needed to increase its performance. In every enterprise it is essential to measure and evaluate a performance by the appropriate chosen indicators of performance (Hammer, 2007).

Despite these facts, there occurs the neglect of financial management in companies, which results in financial difficulties of various degree and character. If a company management does not secure sufficient financial resources (own or foreign), sooner or later, its financial stability will be disrupted and performance (subside) will decrease under the minimum required level and the company will go to insolvency, which can result in existing problems of the company. Unsuccessful features of management failure were portrayed by lots of means. Four general expressions that commonly occur in literature are failure, insolvency, neglect, and bankruptcy. (Altman \& Hotchkiss, 2006). According to the degree of severity, we can classify the financial problems into three groups (Vlachynský et al., 200): Insufficient profitability, where the rate of return on capital tied in a company falls below the normal level in a particular business sector.

Relative illiquidity (insolvency) that can be temporary - when inability to pay can be caused by some unfavorable causality or chronical - when in a long-termed period, a company has not been able to produce sufficient monetary resources for paying of liabilities by its common activity. We can divide it to primary insolvency and secondary insolvency: Primary insolvency that is formed when defaulting receivables not paid on time are lower than defaulting liabilities not paid on time. Companies that are in primary insolvency, recall a secondary insolvency of their suppliers; and, secondary insolvency, when a sum of company receivables that are not due in a required period is higher than a sum of its on-time defaulting liabilities.

Absolute illiquidity - extension, which occurs when company liabilities are higher than real value of a company property. In practice it means that a company already spent all its equity, it owes more than owns. 


\section{Financial Indicators of a Company Decline}

The most important part of a financial company management is an evaluation of its financial situation, which is a summary expression of level of all company activities that a company presents itself. It is necessary that any financial decision is supported by financial analysis (Synek et al., 2011). By financial analysis we can understand a sum of activities, the object of which is to gain and to complexly evaluate a company financial situation. Financial analysis consists of perspective analysis (oriented at the future) and retrospective analysis (oriented at the evaluation of the present by results from the past). Through the retrospective analysis we can reveal causes that determined a condition of corporate finance, i.e. financial situation, and so determine company decline causes. In the research we are oriented mainly on the classic methods of financial performance evaluation. We are conscious of the fact that modern methods of performance evaluation are also currently used, but many enterprises in Slovakia still do not use these methods properly and sufficiently, thus we emphasize its importance and necessity. We also think that the modern methods should be used but as a completion of classic methods. Another reason of its emphasis is that they have a big significance in a decline indicating of which they can reveal much. When identifying possible decline indicators that can define causes of a decline, it is necessary to choose indicators which are able to capture a decline situation (Landa, 2009). In case of insolvency, liquidity ratio indicators and net working capital can show us a lot in connection with the golden balance rule. In extension, we should be mainly interested in debt ratio indicators, differential indicator of equity, and other ratios of capital structure. Profitability and activity ratios serve to us as supplementary characteristics of decline causes that provide a broader picture.

It is necessary to emphasize that values of indicators are very sensitive to sector and department competence because every company has different structure of assets and liabilities. Horizontal and vertical analysis can tell us a lot about that, in connection with the golden balance rule, where companies should cover its long-term assets by long-term resources (liabilities). Liquidity ratios inform us about a company ability to repay its liabilities, where in every company the basic role of financial manager should be securing a required liquidity. Debt ratios determine a range in which a company uses foreign capital to finance of its needs. High part of equity makes a company stable and with a low part of equity a company is unstable. With increasing of indebtedness there rises a business risk as well and it is very important for a company to find a proper structure of its resources. Profitability ratios tell us about a business activity success. They represent various forms of profit rate as a generally accepted indicator of profitability. Activity ratios inform us about a level of use of particular asset parts.

\section{Research Question and Research Hypotheses}

The research question of the study is:

What are the main causes of company decline formation from a financial point of view?

Based on the research question, the following research hypotheses guided the study:

$\mathbf{H}_{1}$ : Companies' decline is caused by insufficient companies' liquidity in connection with its excessively high indebtedness. 
$\mathbf{H}_{2}$ : A decline is caused by insufficient companies' profitability as well.

The condition of successful achievement of the main objective is the development of the partial targets that are intended to evaluate the research issue based on gained theoretical knowledge, to analyze assessment of the research results together with drawing up the drafts for education, theory and economic practice in fields of the financial aspects of a company crisis management.

\section{Method}

\section{Procedures and Sample of Studies}

The first step needed is choosing the topic which is currently affected by high considerable time in the present. Within working procedures, very important step is obtaining of information and its resources, where we derive the data from various sources and it is important to select the data and choose the needed information relating to the given topic. The next procedure relates to characterizing of the research object. It includes choice of the companies, in which the analyses of the given topic are realized. Statistical set is created by all business subjects in Slovakia. The sets that are objects of our research, we call the basic sets, are created by all Slovak industrial companies. Since in practice it is very often impossible to examine the whole basic set, what is our case as well, it is necessary to work with the chosen set - the sample. In our study, the sample consists of 143 industrial companies in Slovakia where the selected criteria of our sample are as follows:

The sector, which are companies active in. According to the statistical classification of economic activities the distinguishing criterion is SK NACE C - industrial production. Industry sector selection is influenced by the fact that companies most often go to decline right in the industrial production. It is followed from the analysis of the portal indexpodnikatela.sk which compared data from 200410 enterprises for 6 years. This was also confirmed by the analysis of CRIF Company - Slovak Credit Bureau which states that in 2014 a record in amount of declines was reached where the riskiest sectors were industry, trade, and construction.

Regarding the size of the companies, we are interested in small and medium-sized companies, which compose over 99 percent of business subjects in Slovakia and have driving force in the national economy. The criterion is a turnover up to 50 million euro and the number of employees is up to 249 that we choose based on European Commission Regulation n. 2003/361/EC. Moreover, the next factor involves the ownership type, where we select private companies - domestic.

The next criterion is the legal form of business, where we take into account capital companies which have high presence on the market, for example, join stock companies and limited companies. We excluded personal companies and state companies to which the Act on Bankruptcy and Restructuring is not related.

The subject condition, where we distinguish a group of companies in decline - bankruptcy or restructuring, and a group of healthy companies, active on the market is another criterion.

The active companies are companies active on the market, legal entities which belong to financially healthy companies where there are not detected negative cases. By the group of decline companies, bankruptcy or restructuring proceeding may not be primary result in bankruptcy or restructuring. They may come to stop for various reasons, therefore we take 
into account only companies that had announced status "approved restructuring" or "declared bankruptcy".

We took into account companies that got involved into decline within years 2014-2016, where last testing period in our research was the period before decline; so, for example, if a company got into decline in 2014, we tested financial statements for the past three periods reported before decline, for instance, for years 2013, 2012, and 2011. In case of healthy companies, we tested financial statements for years 2013-2015. We are aware that the studied time period for the analysis' needs would be as longest as possible but there are some limitations that oppose us to define longer time period; following this, there is a fact that companies have an obligation from the law to publish financial statements but this obligation is not fulfilled, information continuity is not preserved, and in some cases, financial statements are failed or are incomplete.

\section{Information Sources}

Information sources are financial statements of the sample, depreciation plans, and other internal documents, as well as consultations with the competent employees, information in Commercial Journal and Commercial register, restructuring plans, reviews, and other documents needed for the research. Furthermore, there are necessary information obtained from various databases like Albertina, Magnusweb, and portal finstat.sk. The success of achieved results of our study is limited by possibilities of obtaining the needed data about the sample in Slovak economy and is conditioned by discarding of some companies from our sample for various reasons such as absence of possible exports of data to format .xls or .csv, publication of only partial data, absence of financial statements in some companies, filtration inability of companies according to our requirements, and insufficient explanatory power of statements for research purposes. Our final sample consists of two groups of companies including healthy and in decline, as follows: Fourty restructuring companies, thirty-two bankruptcy companies, and seventy-one healthy companies.

\section{Used Methods}

After obtaining the needed information we apply theoretical knowledge and its practical application in particular companies by which we come to the research results. For this purpose, we use various methods and among them, analysis is the first step of wise decisionmaking (Blaha \& Jindřichovská, 1994). Every decision-making must come out of results of financial analysis. By synthesis the results are summarized in the study results and in discussion. Moreover, we use a comparison, induction, and deduction. By a method of scientific abstraction, we abstract from certain facts for undertaking the required research. In application part of the research results we use statistical methods, the basic purpose of which is obtaining and providing the needed data in a form that makes its processing and evaluating easier. Following these methods, we use quantitative methods of descriptive statistics (it is oriented on various methods how to obtain, use, and present collected data with its description through specific statistic methods) and methods of mathematical statistics (it is used if obtaining of all data is not always possible from various reasons and concludes based on gained partial data and generalization of obtained results about the whole basic set). We test 
the set hypothesis on 0.05 Alpha defined level of significance. Since we are mainly interested in which indicators and characteristics have significant impact on financial company health and we compare two basic groups (healthy companies and decline companies), we use u-test that is an analogy of t-test and that is stronger in case of normality disruption. The statistical use is in progress in MS Excel and in a statistical program Python, where the test is carried out through a module of StatsModels.

\section{Results}

There are various causes of a decline formation of chosen industrial companies. Largely, it is a combination of market impacts in industrial sector with companies' inability to immediately and radically decrease the fixed costs of acquired investments into technology equipment, problems with allocation of sources into assets that does not bring an added value or does bring it on an insufficient level, a result of which is an insufficient profitability. It creates a time loop which causes a decline. Despite of companies' effort to undertake new orders there were not noticed such business transactions that are required for securing of a capital turnaround. The companies felt financial problems that resulted in primary or secondary insolvency which further culminated in its extension in amount of 46 (26 companies were in insolvency decline). Table 1 represents the golden balance rule of decline companies.

Table 1

The Golden Balance Rule of Decline Companies

\begin{tabular}{lccll}
\hline Golden Balance Rule & Bankruptcy & Restructuring & All & \% Ratio \\
\hline Overcapitalized & 7 & 4 & 11 & $15.3 \%$ \\
Undercapitalized & 25 & 36 & 61 & $84.7 \%$ \\
& & & 72 & $100 \%$ \\
\hline
\end{tabular}

In the bankruptcy group there were 25 companies undercapitalized at least 2 years before the decline, what is the evidence of not following the golden balance rule. The companies covered their non-current assets by short-term resources. From the current-assets point, net working capital was negative, thus there was an uncovered debt that speaks about the insufficient liquidity of companies. The remained 7 companies were overcapitalized they were only very slightly above the required level. In the restructuring group there were 36 companies undercapitalized minimum of one year before its decline. Main reasons for undercapitalization were in increasing the loss and decreasing the sum of current assets caused by decreasing of short-term receivables or supplies in connection with high rising of short-term liabilities or reaching on short-term company reserves. In rest of the companies, the most frequent reasons of their slight overcapitalization were the fact that the companies took a loan one year before decline but nevertheless were not able to repay it. When comparing decline companies with healthy companies, we state that most of the healthy companies were overcapitalized, consequently non-current assets were covered by long-term sources and positive net working capital verified a good liquidity of companies. In the 7 remaining companies, undercapitalization occurred but by 5 of them, there was only slight undercapitalization. Of course, in the future, the companies should take care of themselves and secure following of the golden balance rule. When we have a look at liquidity of the two remaining undercapitalized companies, we can see they do not have a problem with solvency. 
In our research, we work with the evaluation of median of testing company sample. We agree that the average provides higher amount of information about a particular result, but it is also sensitive to extreme values. That is true in our cause as well since there is not a sample with normal characteristics. In that case, the resulting data may be misrepresented. Hence, median has a better explanatory power than the average for our research.

Table 2 shows the chosen characteristics of healthy companies and decline companies in last following period.

Table 2

Chosen Characteristics of Healthy Companies and Decline Companies in Last Following Period

\begin{tabular}{ccccccc}
\hline & Median $_{\mathrm{b}}$ & Average $_{\mathrm{b}}$ & Median $_{\mathrm{r}}$ & Average $_{\mathrm{r}}$ & Median $_{\mathrm{z}}$ & Average $_{\mathrm{z}}$ \\
\hline L1 & 0.01 & 0.06 & 0.01 & 0.01 & 0.82 & 2.65 \\
L2 & 0.22 & 0.41 & 0.37 & 0.37 & 1.89 & 4.41 \\
L3 & 0.25 & 0.49 & 0.53 & 0.54 & 2.27 & 5.4 \\
\hline TDTA (\%) & 145 & 73889 & 131 & 2930 & 31.5 & 160.2 \\
\hline TETA (\%) & -45 & -73789 & -31 & -2830 & 68.5 & -60.21 \\
\hline LVR & -1.33 & -39.65 & -1.96 & 26.25 & 0.45 & 16.55 \\
TAE & -0.27 & 4.72 & -0.74 & 16.9 & 1.39 & 2.71 \\
CLTA (\%) & 98.8 & 2237 & 76.6 & 93 & 18 & 19.9 \\
INV & 8.56 & 40.78 & 3.32 & 10.53 & 0.6 & 1 \\
\hline IC & -17.77 & -25092 & -16.13 & -38.5 & 19.3 & 4511 \\
ROA & - & - & - & - & 15.49 & 16.35 \\
\hline ROE & 36.32 & 6.66 & 40.41 & 35.90 & 21.7 & 31.33 \\
\hline ROS & - & - & - & - & 8.77 & 5.87 \\
\hline TAP & 182.76 & 243.74 & 329.13 & 381.69 & 246.43 & 301 \\
\hline TLP & 268.54 & 312.69 & 261.93 & 341.08 & 50.48 & 69.72 \\
\hline TRP & 51.71 & 107.92 & 96.09 & 125.96 & 57.59 & 76.4 \\
\hline
\end{tabular}

In the decline companies, median of every liquidity degree achieves lower values than the required value. We can say the same about the average 2 years before a decline. First degree liquidity values are low in most of the companies, not achieving even a lower-bound of a recommended interval (0.2-0.9), which every company should achieve regardless the sector and object of its business activity. Sum of short-term liabilities highly exceeds the sum of liquid assets. Only a few companies achieve a value within the recommended interval, but in most cases it is about a period of two-three years before a decline. A median does not exceed 0.04 value that testifies about very bad companies' solvency. In case of second degree liquidity we cannot state positive results as well and in case of the restructuring companies, only 6 of them achieved the recommended value (1-1.5). In case of the bankruptcy companies, 10 of them achieved it only because there are cases when companies pointlessly cannot convert their high amount of current receivables to cash and have low first grade liquidity values. Concurrently, it is a period of one year before decline with first grade liquidity. A median, likewise an average, does not show the required values. All the 40 restructuring companies and all the 32 bankruptcy companies do not achieve third degree liquidity in a required level (2-2.5). Generally speaking, it can be stated that almost neither of all the companies do not approximate to recommended values for one-year period before a decline; furthermore, there are extremely low values in case of every liquidity grade. The companies are not able to fulfill their liabilities properly on time. 
According to the golden financing rule, ratio between equity and foreign capital should be approximately equal. With regards to the fact that every company has different indebtedness depending on various reasons, we determine the maximum limit of debt ratio to the level of $70 \%$; thus the border of equity ratio, under that companies should not subside, is $30 \%$. In the bankruptcy group, only 4 companies have indebtedness lower than $70 \%$, among them there are cases two or three years before a decline. In the last year before a decline only one company achieved lower indebtedness than $70 \%$ and it is $49 \%$. The company has a leverage value in a required interval as well (1.95). The main reason of its bankruptcy was its inability to repay its loans. The mean value of debt ratio achieves $145 \%$ in one-year period before a decline that is extremely high number while short-term liabilities create most of all liabilities of the companies, by which current assets are covered. A leverage should not exceed the value of 3, which is managed only by four companies, by one of which, it is 2 years before a decline. We have to watch the negative result with justifying that company is in extension, so the negative value of leverage is caused by the negative equity (likewise in some other indicators). The mean value of ratio for one-year period before the decline achieves the negative value (-0.27). Financial independence grade confirms the results of insufficient liquidity where the mean value achieves -1.33 one year before a decline and neither of all companies achieves the recommended value. In case of insolvency indicator, it is the same. The interest coverage mostly achieves negative values and the median achieves the limit of 17.77 that shows us the companies' inability to pay the price of its borrowed capital while from the results it is seen that it is about a short-term capital - the highest limit of indebtedness consisted from a short-term indebtedness of the companies. In the restructuring group there are similar results. Only 7 companies achieved lower indebtedness than $70 \%$ but this was more than one year before a decline. Likewise, it is in other ratios. Generally, ratios achieve slightly better results in case of 2 or 3 years before a decline compared to the bankruptcy companies. If companies had realized its bad financial situation sooner, they would have prevented a bigger deterioration of this situation. We can evaluate that the ratios of capital structure portray excessively high indebtedness level of the companies in both groups of companies in decline and practically all of them are influenced by excessively high liability level, mainly short-term liabilities; even some of them in combination with negative equity result in the inability to repay these liabilities that led to their decline.

When we have a look at financial statements, as soon as we can see a reported loss in companies and not a profit, it does not make sense to count profitability, mainly in case of return on equity where a company shows a negative equity and loss. In a mathematical way the result is positive, but economic reality does not confirm the positive mathematical result, because a company is not profitable, even it has more debts than assets.

In the group of healthy companies, $19.4 \%$ of them did not achieve the recommended liquidity values. In case of the third grade liquidity, not achieving the recommended value in one of the studied period is mostly influenced by supplies, where it is needed to take into account that every company has a different production cycle and may achieve various values that does not mean a bad result and imminent insolvency. By L1 and L2 some companies do not achieve the recommended values because of high liabilities, where the essential part is created by common bank loans, but in financial statements it is seen that the loans are repaid and sales have a positive trend and have risen during the last three years. Some companies 
hold a high amount of short-term receivables. Liabilities are repaid every year and insolvency is not probable but increasing of short-term receivables condition in order not to threat immediate solvency should be achieved. Out of the mentioned $19.4 \%$ companies, after more detailed researching it is viewed that 4 of them do not have a problem with solvency so far, but 4 remaining companies do not achieve the required values and this should be an exclamation mark of their financial situation condition for them. It is important to remark that achieved liquidity values compared to decline companies are strongly higher and $81.6 \%$ of the companies do not have a problem with solvency. The median of the achieved values of all liquidity grades testifies that as well. The indebtedness ratios show that the companies achieve approximately $30 \%$ of indebtedness that we consider as a good result while short-term indebtedness moves to $18 \%$ or so. Almost no company has a problem with repaying of a borrowed capital and is solvent, some companies that even achieve high indebtedness, are able to bear it and it does not threat the financial stability of the companies. Generally, we can state that the companies that achieve values in the recommended interval do not have a problem with their financial health that is further confirmed by the achieved profitability of the tested companies in a high level as well. Table 3 exhibits the testing of the hypotheses.

Table 3

Testing of the Hypotheses

\begin{tabular}{cccc}
\hline Indicator & P-Value & Indicator & P-Value \\
\hline ROA & 1.16 & TLP & 0.09 \\
ROE & 1.18 & TDTA & 0.26 \\
ROS & 3.29 & TETA & 2.25 \\
L3 & 2.49 & CLTA & 1.65 \\
L2 & 1.57 & INV & 1.28 \\
L1 & 5.41 & IC & 0.03 \\
TAP & 0.05 & LVR & 0.42 \\
TRP & 0.00 & TAE & 0.34 \\
\hline
\end{tabular}

Testing of the hypotheses confirms the achieved results above and shows a significant importance of the impact of liquidity, indebtedness, and profitability on the financial health of companies. Relating to our research question, according to the p-value results, on a 0.05 significance level we can confirm both hypotheses and we can state that declines of companies are caused by insufficient liquidity in connection with its excessively high indebtedness and insufficient profitability. Activity ratios do not have a significant impact on a decline formation.

\section{Discussion}

In connection with an insufficient company performance, the liquidity and indebtedness ratios together with profitability ratios are essential here. Companies also have to take into account the results of analysis in complexly common way that is not applied in Slovakia many times. Afterwards we can come to conclusions of financial analysis and relating financial decisions for the future.

The causes of the insufficient liquidity and of high indebtedness or a combination of them are various. Insufficient equity production in combination with a lack of foreign sources may 
create presumptions for insolvency formation. Reasons for that may be various such as existence of problematic parts of current assets, when companies bind uselessly high amount of cash in supplies or in receivables, operational resources lack for financing of losing business activity (liquidity risk is not often caused by low profitability, many companies achieve profit at the expense on liquidity), inability to secure enough finance by occurrence of incidents, contravention of the golden balance rule (it means lack of long-term sources and so companies cover its non-current assets by shorter sources meaning that a company is under the continuous pressure of sources restoration). On the other side, companies achieve the negative net working capital (uncovered debt), thus, there is elevation of short-term foreign sources above current assets, high profit allocations to split it among owners, failure to follow a relation where the receivables' turnover time should be lower than liabilities turnover time and other. Common reason of insufficient liquidity of companies caused by these problems is their failing management. In companies, many times there occur situations when companies do not realize what may happen by shortening or by lengthening the receivables, by changing of turnover of current assets items, by sales changing, and by drawing loans. The more mistakes there are in a company in liquidity management, the more is a company financial stability subsided. Hence, if current assets are funded by short-term liabilities, it is necessary to manage, monitor, and evaluate this process to secure a company solvency in the future; for example in a company, it is appropriate to make clear what could happen by lengthening of payment due to invoices (to secure no occurrence of insolvency caused by customers), by reducing the payment due to liabilities by suppliers, by increasing and decreasing the current asset items (realizing to the impact on weakening or strengthening liquidity in connection with net working capital) and sales (what would happen with the liquidity when increasing or decreasing sales, how much of additional funds will be needed for securing of sales increasing), and by financing of investments projects (not to threat operating flows, determine a bearable amount of planning investment). Company financial management should police a continuous liquidity planning together with quantifying acceptable insolvency risk and continuous control. There should be secured such structure of assets and sources of its coverage and cash flows that a company solvency would be on required level. Therefore, from financial managers' point, it is necessary to regularly manage current assets and shortterm liabilities, realize consequences of lengthening or shortening payment due to customers' invoices - mainly to significant customers, and constantly secure sufficient cash for payment of corporate liabilities. In short time horizon, securing liquidity is a primary objective of management, even more important than profit itself which cannot ensure enough cash for repaying liabilities (Cisko \& Klieštik, 2013). We secure a required liquidity by regular planning of balance sheet. Current assets should be planned in a way for company operation to be secured and for no limitations of continuous production. Every company has its requirements for current assets; to this end, Ross, Westerfield, and Jaffe (2005) stated that financing of current assets influences a cash condition as well. Time between invoicing and expected income is expressed in days, we mark this indicator as DSO (Days Sales Outstanding). DSO is used for receivables' estimation, it is counted as a ratio between averaged receivables and averaged daily sale (realization) and it serves for determination of days' number of liabilities (Ehrhardt \& Brigham, 2009). It expresses the average time for which a company has to wait from product sale to payment acceptance and helps to overcome 
current assets fluctuations, consequently fluctuations of short-term cash resources necessity as well. The golden balance rule should be followed and current assets should be covered partly by short-term sources and partly by long-term sources (equity and long-term foreign sources), non-current assets must not be covered by short-term sources and financial managers should have their plan as effective as possible, with as high return as possible, and should take into account financing possibilities and take into account unexpected occasion for which there should be planned reserves in a needed sum. It also should not be forgotten that time of received receivables should not exceed the time of liabilities repayment -for a company to change necessary short-term receivables to cash by which will reimburse its short-term liabilities.

In our opinion the indebtedness should not exceed $30-60 \%$ of whole capital, depending on a sector in which a company moves. It is important for companies to take care of indebtedness analysis and try to follow the recommended values of particular indicators in combination with their own deliberation. It is not possible to do the debt analysis independently, thus, we have to take into account other indicators as well. In connection with the creation of suitable financial structure, there are mainly profitability ratios that strongly impact indebtedness because profitability is related to capital costs that increase the entire company costs. An enterprise is stable with high equity ratio and is unstable with low equity ratio. Equity is more expensive because risk of an owner is higher than a creditor's risk, but not endlessly. Too high amount of foreign capital can threat company stability and finally its existence as well. Inconsiderable is the relation between liquidity structure in connection with company indebtedness. The reason of low ratio of the most liquid assets in companies is that its operation activity is losing. They do not fulfill one of the main business activity goals - profit maximization and they only survive on the market. This is supported by the provision of loans that serve only for balance of liquid assets ratio. Actually, decisive ratio of these loans does not have a curative function because from a long-term period it is not going to form a better liquidity structure - in fact, insolvency is deepening and in foreign sources structure there is an increasing bank loans ratio which, in the end, the loans are included in non-paid liabilities. Low proportion of liquid assets influences the indebtedness. Because of assets financing, there is an increasing foreign sources ratio and simultaneously costs of its purchase rise as well. In a company, relation between liquidity structure and indebtedness should be analyzed individually. The burden on foreign sources is influenced by current assets structure (that tell us about capital binding in assets with lower liquidity grade), consequently by liquidity structure and indebtedness level. We can define and explain the relationships between the liquidity structure and the level of indebtedness. In the first grade liquidity, the sum of callmoney should approach the sum of short-term liabilities as much as possible (value 1). In the second degree liquidity, financial accounts should predominate by most liquid assets, because high sum of receivables (that have lower liquidity) can cause a company to miss the change of it in cash in due time and simultaneously, a company allows its illiquidity customers to enter its operation cycle and cash flow. In case of disproportionately high short-term receivables, a company should lower the sum in favor of its financial accounts that are the most liquidity part of the current assets. If a receivables condition is high, a second grade liquidity structure is negative in economic environment with abnormally high solvency. The most visible is the 
dependence between loan risk and second grade liquidity because high degree of receivables is not considered by standard source of liquidity - solvency level is increased by a turnover receivables period. In the third degree liquidity the sum of the current assets should exceed the sum of a short-term liabilities (value 2-2.5). Supplies should form the smallest part characterized by lower liquidity than the short-term receivables. Too high sum of supplies increases the necessity of the foreign sources that has a direct impact on decreasing of profitability. Its sum is, of course, influenced by a particular production cycle in every company. Companies that work with minimal amount of supplies or even without supplies (e.g. companies that provide services), can have the third grade liquidity as equal as other companies; this does not mean they have a decreased ability to pay liabilities. Short-term liabilities should not exceed approximately $40 \%$ of the sum of the current assets.

In general, it is true that company goals, in the form of high liquidity and high profitability, are contradictory. High liquidity "goes at the expense of profitability" and vice versa. Every company should look for an optimal relation between its liquidity and profitability dependent on its current financial situation. Concurrently, there should not been held too high amount of cash at the expense of investment possibilities but simultaneously, it is appropriate to think of having a necessary amount of cash for liabilities reimbursement. From the influence of financial capital structure on profitability, we can say that when creating the capital and financial structure, companies had better take into account the leverage effect and leverage risk and find an appropriate ratio between its own and foreign sources in a capital structure. Regarding these facts, generally, we cannot claim how much \% of foreign capital ratio a company should have. When increasing a foreign capital ratio, a company should consider a relation of return on assets and interest rate and finally, its determination depends on the actual assessment and decision of financial managers.

It's important to emphasize that currently in Slovakia, companies still neglect classic methods of a company performance assessment and many times they do not take them into account or they apply it in an insufficient level. We firmly believe that if companies regularly controlled their financial situation through these methods, they would not go into decline and could take measures by which they would be able to avoid imminent decline. If appropriate indicators in suitable interacting combination are used, we can speak about a particular complexion of a financial analysis. By using of modern methods there the aspect of owners' value maximization would be taken into account and thus companies would have a trustworthy picture about their financial situation. Interpretation of particular results of chosen indicators and their relations are very important. Firstly, it is important to realize that "when in math, two plus two equals four, in economy it is not true" and results of indicators have its economic sense. The typical example in our research is a positive return on equity of decline companies that is recognized because of its negative equity and achieved loss. Hence, it is essential for a company to take into account all economic aspects in analyzing.

\section{Conclusion}

In the current business environment, the importance of companies' financial management and financial situation assessment are sometimes neglected and the first signals of possible financial difficulties formation are ignored that can result in companies' decline. The solution is introducing the crisis management by formal and informal procedures. The most important 
aspects of the crisis management are financial aspects, therefore, the crisis management is closely connected with the financial management.

A proper company management should continuously control its financial situation and prevent the decline. Securing a company's financial stability is the basic assumption of its financial health. When maintaining a financial stability, financial managers should secure liquidity values on a required level. Yield is the important indicator of financial company performance that is measured by profitability ratios and it must come out from the profit and not from its management result. It is important to realize that if a company achieves a particular profit level, it does not mean that a company has enough cash. Therefore, a company should not be evaluated only by revenues, costs, and profit, but also by incomes and expends that are displayed in a cash flow statement. Capital structure indicators speak about company indebtedness which a company should follow in a bearable level and must find a proper ratio between foreign and own sources to maintain a necessary financial stability. An impact of indebtedness to profitability is important here, because whole capital costs are in connection with profitability, where these costs pump a considerable part of a profit and achieved profit height has an impact on profitability ratios. By respecting various theories of optimal financial structure, in our opinion an appropriate financial structure means that its determination depends on final decision of management by taking into account all the necessary factors that have an impact on a financial structure. The question is that "Is it better to have a high financial stability and lower profitability, or vice versa, or is it more important to have higher return on equity on expense of a lower financial stability?" The proper answer is different by every company and depends on a particular company decision - which alternative will be chosen. Activity indicators show utilization of assets and effectiveness of utilization, when these ratios provide us with a supplementary picture about a company's financial situation. A company should also take into account the relation between liquidity structure and indebtedness where the relation between rising of loan risk and liquidity structure is necessary to be analyzed individually in every company; following this, net working capital should be in a level for the particular parts of current assets to be financed by long-term sources and partly from short-term sources. The golden balance rule must be followed as well and non-current assets must be covered by long-term sources.

In conclusion, there exist various groups of people including owners, managers, creditors, and investors that are interested in as good financial health of a particular company as possible and it is very important for them to know its present or future financial situation. Depending on a goal of a financial analysis, if the use of separate indicators does not provide the sufficient picture about a company's financial situation, it is appropriate to enrich the financial analysis with application of modern methods of company performance assessment.

The set partial goals of our research were fulfilled and the main research goal was achieved by that. From the study results we can answer the research question and state that a company decline is caused by the insufficient companies' liquidity in connection with their excessively high indebtedness. It is essential to note that the insufficient companies' profitability has an impact on a company decline. 


\section{References}

Altman, E. I., \& Hotchkiss, E. (2006). Corporate financial distress and bankruptcy: Predict and avoid bankruptcy, analyze and invest in distress debt. New Jersey: John Wiley \& Sons.

Bernstein, A. B., \& Rakowitz, C. (2012). Emergency public relations: Crisis management in a 3.0 world. Thousand Oaks, CA: Sage.

Blaha, Z. S., \& Jindřichovská, I. (1994). Jak posoudit finanční zdraví firmy. Praha: Management Press.

Cisko, Š., \& Klieštik, T. (2013). Finančný manažment podniku II. Žilina: EDIS, vydavatel'stvo Žilinskej univerzity.

Coombs, W. T. (2007). Protecting organization reputation during a crisis. Corporate Reputation Review, 10(3), 163-176.

Ehrhardt, M. C., \& Brigham, E. F. (2009). Corporate finance: A focused approach. Mason, OH, USA: SouthWestern Cengage Learning.

Frost, W. (2005). ABCs of activity based management. Lincoln: Iuniverse.

Hammer, M. (2007). Jak zlepšit provozní výkonnost. Moderní řizení, 58(9), 32-36.

Král’ovič, J., \& Vlachynský, K. (2011). Finančný manažment. Bratislava: Iura Edition.

Landa, M. (2009). Ekonomika insolvenčního ř́zení. Ostrava: Key Publishing.

Neumaierová, I. et al. (2005). Řizení hodnoty podniku: Nedělejme z podniku záhadu. 1. Praha: Profess Consulting s.r.o.

Ross, S. A., \& Westerfield, R. W., \& Jaffe, J. (2008). Corporate finance. Boston, MA: The McGraw-Hill Irwin. Synek, M. et al. (2011). Manažérska ekonomika. Praha: Grada.

Vlachynský, K. et al. (2006). Podnikové financie. Bratislava: Iura Edition. 